\title{
FOLLOW-UP OF 423 CONSECUTIVE PATIENTS ADMITTED TO THE SPINAL CORD CENTRE, RANCHO LOS AMIGOS HOSPITAL, 1 JANUARY TO 31 DECEMBER 1967
}

\author{
By N. Elane Wilcox, PH.D. and E. Shannon Stauffer, M.D. \\ Rancho Los Amigos Hospital, California, U.S.A.
}

OPINIONS are common among clinical personnel in rehabilitation centres regarding long-term behaviour of discharged patients. Many of these opinions can be substantiated by individual patients. Relatively little has been reported, however, about large numbers of such severely handicapped persons after their return to the wider boundaries of society on the 'outside'. Persons with traumatically induced spinal cord injuries comprise a heterogeneous population when they arrive for treatment: age, sex, cultural structure, education, marital status, experience in working and living are as divergent as human nature itself. They will continue to be a heterogeneous group when they leave the centres with one obvious difference: they will demonstrate a severe and probably permanent physical impairment. Examples of this diversity are portrayed in the follow-up of patients summarised in this report.

A previous study (Wilcox et al., 1970) described the population of the Regional Spinal Cord Injury Centre at Rancho Los Amigos Hospital for the period between I January I964 and 3I December 1967. These figures reported level and cause of injury, sex and age of recipients of injuries as well as duration of hospitalisation and frequency of clinic visits for all persons admitted to the Centre during the four-year period. Table I is a summary of some of these figures and is the basis upon which this report was developed.

\section{TABLE I}

Distribution of Patient Population (423) by Level, Etiology of Injury and sex

\begin{tabular}{|c|c|c|c|c|}
\hline & \multicolumn{2}{|c|}{ Traumatic } & \multicolumn{2}{c|}{ Non-traumatic } \\
\cline { 2 - 5 } & Male & Female & Male & Female \\
\hline Paraplegia = 207 (48.94\%) & $\begin{array}{c}\text { II } 5 \\
(75 \cdot 2 \%)\end{array}$ & $\begin{array}{c}38 \\
(24.8 \%)\end{array}$ & $\begin{array}{c}27 \\
(50 \%)\end{array}$ & $\begin{array}{c}27 \\
(50 \%)\end{array}$ \\
Quadriplegia = 216 (51.06\%) & $\begin{array}{c}157 \\
(80.5 \%)\end{array}$ & $\begin{array}{c}38 \\
(19.5 \%)\end{array}$ & $\begin{array}{c}14 \\
(67 \%)\end{array}$ & $\begin{array}{c}7 \\
(33 \%)\end{array}$ \\
\hline
\end{tabular}

The original study included 423 persons. A review of the records indicates that two of the patients had extensive brain damage and were transferred to another service in the hospital. One child was seen only in the pediatrics department and was also excluded from follow-up. The final tally of patients to be followed was 420 .

Tables II and III indicate the degree of success in locating the 420 former patients. 'Follow-up' is defined as actual communication at some time since 
I January I97I with the person or a responsible agency presently providing him services. Many former patients were seen and interviewed in clinic in this hospital; others were reached by telephone. Hospital records from other institutions, as well as informative correspondence from attending physicians, public health nurses and patients or their families, were considered as follow-up. A few home visits were made. At least 85 per cent. of all oral and written communication was conducted by persons acquainted with patients when they were initially in the Centre.

TABLE II

Follow-up of Patient Population (346) with Traumatic Lesions

\begin{tabular}{|c|c|c|c|}
\hline Year & Total cases & Cases located & Cases completed \\
\hline I964 & 66 & 60 & 60 \\
1965 & 89 & 74 & 70 \\
1966 & 100 & 83 & 77 \\
I967 & 91 & 67 & 63 \\
\hline Totals & 346 & $284(82 \%)$ & $270(78 \%)$ \\
\hline
\end{tabular}

TABLE III

Follow-up of Patient Population (74) with Non-traumatic Lesions

\begin{tabular}{|c|c|c|}
\hline Year & Total cases & $\begin{array}{c}\text { Cases located } \\
\text { and completed }\end{array}$ \\
\hline I964 & I5 & I2 \\
I965 & I9 & I2 \\
I966 & I6 & I2 \\
I967 & 24 & I9 \\
\hline Totals & 74 & $55(74 \%)$ \\
\hline
\end{tabular}

In addition to those with whom correspondence or conversation was exchanged, there were I4 who, according to hospital records, came to some clinic or received supplies from Rancho Los Amigos Hospital since I January I97I. These people were not interviewed by persons contributing to this survey. Such notes as were dictated by the physician in the clinic establish current follow-up. Seventy-seven per cent. of the total group has been accounted for as a part of this report.

Non-traumatic lesions caused paralysis in 74 persons in the series. Specific etiologies included tumours, seriously complicated herniated discs, spondylosis syringomyelia and infectious processes. The traumatically induced lesions accounted for paralysis in 346 patients. These individuals comprise the content of this study. Eighty-two per cent. of the traumatically injured persons have been located since I January I97I. 


\section{MORTALITY AND SURVIVAL}

Fifty patients (I 4 per cent.) are known to be dead. Survival time from injury to death ranged from 4 months to 32 years. Two-thirds of the deaths occurred within 5 years of injury, as noted in Table IV. Thirty-two persons with cervical cord lesions and I8 paraplegic patients are known to have died. (Fifty-one per cent. of all lesions treated were at the cervical cord level; 64 per cent. of all deaths were among quadriplegic patients.)

\section{TABLE IV}

Duration of Survival from Onset of Injury for all known Deceased Patients

\begin{tabular}{|c|c|c|}
\hline \multicolumn{3}{|c|}{ Traumatic injuries } \\
\hline \multirow{2}{*}{$\begin{array}{l}\text { Years of } \\
\text { survival }\end{array}$} & \multicolumn{2}{|c|}{ Deceased } \\
\hline & Total & Quads \\
\hline$<$ I year & 3 & 3 \\
\hline I year; $<2$ years & IO & 5 \\
\hline 2 years; $<3$ years & 7 & 5 \\
\hline 3 to 5 years & I4 & 9 \\
\hline 5 to Io years & 8 & 7 \\
\hline Io years & 8 & 3 \\
\hline Totals & 50 & 32 \\
\hline
\end{tabular}

Causes of Death. The principal cause of death among quadriplegic patients was pneumonia, which accounted for ten. Pneumonia was given as the cause of death for one paraplegic patient. Cancer resulted in six deaths, equally distributed between paraplegic and quadriplegic patients. Various cardiac conditions were given as cause of death for five persons as shown in Figure I. Conditions considered to be closely associated with the disability, and probably avoidable, including overdoses of drugs and/or alcohol, suicide, and multiple pressure sores with sepsis accounted for 17 deaths ( 34 per cent.). Additional information for this group of patients shows that survival from injury to death ranged from I to I 5 years. No deaths occurred less than I year from onset of paralysis; nine persons died between 2 and 5 years after injury. Sixteen died before the sixth anniversary of their injury. No patient in this group was married at the time of death. Eight were legally single at injury, although several were known to have had 'arrangements' and were living with a partner. Several were married at injury and several were parents. Four of the 17 were known to have received their injuries in some way associated with unlawful behaviour involving police action. Eight had some history of the use of drugs. Thirteen of the 17 were Caucasians.

Current Status of Surviving Persons. Through the efforts of physicians, therapists and rehabilitation nursing personnel preventing certain fatal complica- 
tions and teaching methods of gaining independence in self-care, spinal cord injured persons have moved from the role of the bed-ridden invalid, often a burden to others and a curse to themselves, toward a goal of reassimilation into society. Widely divergent examples of behaviour were exhibited by the surviving persons located by this study. Most of them were found to be living in California, particularly in the Southern Area. Two are in England; one is in South America and the others are scattered over the continental United States. For some, follow-up has revealed progress in school, employment, social adjustment; for others, activity has been floundering; for some, it seems to be aimless; and in still other cases the picture is simply dismal.

17 deaths probably avoidable

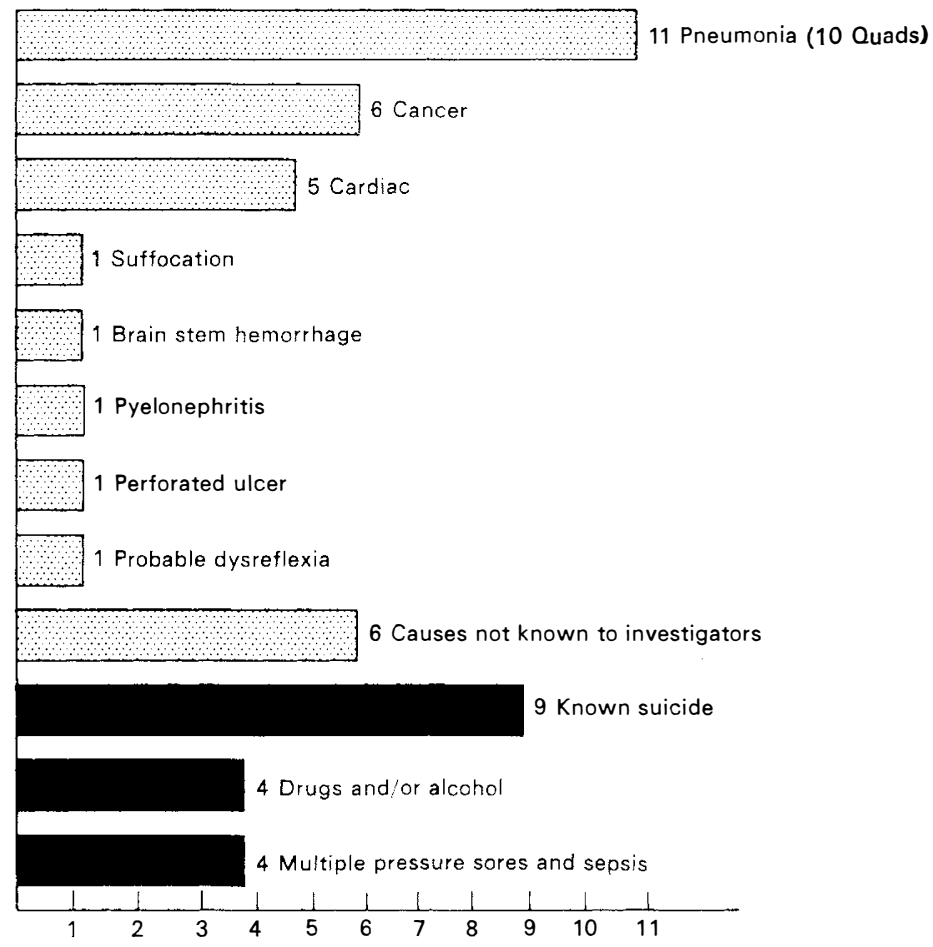

Because standards for behaviour assessment are few, choices of foci for investigation have been arbitrary and are therefore open to criticism. Success and failure are admittedly judgmental descriptions of performance. After lengthy deliberation, several criteria were selected in an attempt to describe some aspects of this very heterogeneous population and to identify some possible determinants or influences of behaviour following injury.

Age at Injury. (Table V). Persons 40 or more years of age at injury totalled 59. Fifteen of these were deceased; I3 were not interviewed. Known survivors, totalling $3 \mathrm{I}$, included seven females. Every woman was or had been married at the time she was injured; six were part-time or full-time housewives at that time. One has since separated from her husband and one has become a widow. None has 
remarried. Two are presently living with husbands and families; two with other family members-children or siblings. Five of the seven have children. None is in a nursing-home. Three were employed at injury; one is presently employed. She is a nurse working in the office of her husband, a physician. Her injury is incomplete and she is able to walk with braces. A second female, a professional diesel truck driver at the time she was injured, has gone to college and received her Associate of Arts Degree since her injury. She has been accepted at a university to continue her education in journalism this fall. She and one very functional incomplete quadriplegic female are living alone with minimal or no attendant care. Females were about equally divided in terms of their level of injury.

TABLE V

Contrast of Patient Population by Age Groups and Level of Injury

\begin{tabular}{|c|c|c|c|c|c|c|}
\hline & \multicolumn{3}{|c|}{$\begin{array}{l}\text { Age at injury } \\
40+\text { years }\end{array}$} & \multicolumn{3}{|c|}{$\begin{array}{l}\text { Age at injury } \\
\text { I4 to I9 years }\end{array}$} \\
\hline & Para & Quad & Total & Para & Quad & Total \\
\hline Not located & 5 & 8 & I3 & 8 & 9 & I7 \\
\hline Known dead & 3 & I2 & I5 & 4 & $6^{*}$ & IO \\
\hline Followed & I 5 & I6 & $3 \mathrm{I}$ & 26 & 55 & $8 \mathrm{I}$ \\
\hline Totals & 23 & 36 & 59 & 38 & 70 & 108 \\
\hline
\end{tabular}

Twenty-four males in the 40-plus category were located; I5 were married at injury; I4 have remained married to the same spouses. Four were single at injury and remain so. No one has remarried. One of the I4, a quadriplegic whose wife is blind, is in a nursing-home; the others live with their families, some requiring the service of paid attendants. Most of these men were employed at injury; one was retired. There was one professionally trained man in this group. Three of these patients receive compensation for injuries sustained in their employment. One veteran receives compensation for another unrelated service-connected disability. Several of these males stated that they had tried to learn a new trade or skill. At the present time, none is regularly employed. At least half of this group receive some type of welfare assistance.

Quite fortuitously, the decision was made to look closely at the group at the lower end of the age-range in the series, i.e. those injured between the ages of 15 and I9 years. One hundred and eight persons comprised this category. Ten are known to be deceased; $\mathrm{I} 7$ were not located. Known survivors, totalling 8I, included nine females. None of the 8I was married at injury. Two females are now married; one is widowed and one married and divorced. Two have their own children, born since injury with normal delivery. Two of the females are quadriplegic; they have attendant help. One of these is married and the mother of a child. None of the paraplegic females has attendant help. One lives alone, a second lives with a similarly disabled friend; the others are with their families. Three are in college, and three are full-time employees. 
TABLE VI

Group B: Persons Presently Employed

\begin{tabular}{|c|c|c|c|c|c|c|c|}
\hline $\begin{array}{l}\text { Identifying } \\
\text { number }\end{array}$ & $\begin{array}{l}\text { Level of } \\
\text { injury }\end{array}$ & $\begin{array}{l}\text { Age at } \\
\text { injury }\end{array}$ & Sex & $\begin{array}{l}\text { Education } \\
\text { at injury }\end{array}$ & $\begin{array}{l}\text { Training } \\
\text { since } \\
\text { injury }\end{array}$ & $\begin{array}{l}\text { Lives } \\
\text { with }\end{array}$ & $\begin{array}{c}\text { Present } \\
\text { employment }\end{array}$ \\
\hline $\begin{array}{c}\text { B-I } \\
\text { B-2 } \\
\text { B-3 } \\
\text { B-4 } \\
\text { B-5 } \\
\text { B-6 } \\
* \text { B-7 } \\
* \text { B-8 } \\
\text { B-9 } \\
\text { B-10 } \\
\text { B-I I } \\
\text { B-12 } \\
\text { *B-I3 } \\
\text { *B-I4 } \\
\text { *B-15 } \\
\text { B-I6 } \\
\text { B-17 } \\
\text { B-I8 } \\
\text { B-19 } \\
\text { B-20 } \\
\text { B-2I } \\
\text { B-22 } \\
\text { B-23 } \\
\text { B-24 } \\
\text { B-25 } \\
\text { B-26 } \\
\text { B-27 }\end{array}$ & $\begin{array}{l}\text { C6 inc. } \\
\text { L2, } 3 \text { inc. } \\
\text { CI, } 2 \text { inc. } \\
\text { T5 } \\
\text { CI inc. } \\
\text { C5, } 6 \\
\text { C4, } 5 \\
\text { C6, } 7 \text { inc. } \\
\text { L2, } 3 \\
\text { T3, } 4 \text { inc. } \\
\text { TI2 } \\
\text { LI } \\
\text { C7, } 8 \\
\text { C5, } 6 \\
\text { T4, } 5 \\
\text { C8 } \\
\text { T8 } \\
\text { TI2, LI } \\
\text { TI I } \\
\text { C6, } 7 \\
\text { C4, } 5 \\
\text { T5 } \\
\text { C7, TI } \\
\text { L5, S I } \\
\text { C4 inc. } \\
\text { C5 in } 5 \\
\text { C4, }\end{array}$ & $\begin{array}{l}17 \\
38 \\
16 \\
22 \\
33 \\
24 \\
18 \\
21 \\
49 \\
37 \\
26 \\
17 \\
17 \\
\\
37 \\
15 \\
32 \\
27 \\
26 \\
23 \\
\\
16 \\
24 \\
21 \\
16 \\
20 \\
19 \\
36 \\
19\end{array}$ & $\begin{array}{l}M \\
M \\
M \\
M \\
F \\
M \\
M \\
M \\
F \\
M \\
F \\
F \\
M \\
F \\
M \\
M \\
F \\
F \\
M \\
M \\
M \\
M \\
F \\
M \\
M \\
M \\
M\end{array}$ & $\begin{array}{l}\text { I2th grade } \\
\text { Ioth grade } \\
\text { I2th grade } \\
\text { Med. lab. } \\
\text { Pre-med. } \\
\text { I2th grade } \\
\text { R.N. } \\
\text { I2th grade } \\
\text { I2th grade } \\
\text { Teaching degree } \\
\text { 9th grade } \\
\text { M.A. } \\
\text { B.S. } \\
\text { Teaching degree }\end{array}$ & $\begin{array}{l}\text { Yes } \\
\text { No } \\
\text { No } \\
\text { Yes } \\
\text { Yes } \\
\text { Yes } \\
\text { E.D.P. } \\
\text { Yes } \\
\\
\text { Yes } \\
\text { Yes }\end{array}$ & $\begin{array}{l}\text { Father } \\
\text { Mother } \\
\text { Mother } \\
\text { Spouse } \\
\text { Parents } \\
\text { Attendant } \\
\text { Spouse } \\
\text { Parents } \\
\text { Spouse } \\
\text { Spouse } \\
\text { Alone } \\
\text { Alone } \\
\text { Alone } \\
\text { Spouse } \\
\text { Spouse } \\
\text { Spouse } \\
\text { Alone } \\
\text { Parents } \\
\text { Spouse } \\
\\
\text { Spouse } \\
\text { Parents } \\
\text { Spouse } \\
\text { Parents } \\
\text { Spouse } \\
\text { Attendant } \\
\text { Spouse } \\
\text { Parents }\end{array}$ & $\begin{array}{l}\text { Insurance agent } \\
\text { Truck driver } \\
\text { Furniture factory } \\
\text { Time control devices } \\
\text { Med. lab. tech. } \\
\text { M.D., pathology } \\
\text { *Family business } \\
\text { *Owns beer bar } \\
\text { R.N. } \\
\text { Salesman/clothing } \\
\text { Cashier } \\
\text { Typist, insurance Co. } \\
\text { *Stamp shop \& student } \\
\text { placement centre } \\
\text { *Real estate office } \\
\text { *Watch repairing } \\
\text { Computer programmer } \\
\text { Dental hygienist } \\
\text { Teacher } \\
\text { Dispatcher with fire de- } \\
\text { partment } \\
\text { Engineer } \\
\text { Social worker } \\
\text { Electronic tech. } \\
\text { Bookkeeper } \\
\text { Farmer } \\
\text { Paints Christmas cards } \\
\text { Teacher, basketball coach } \\
\text { Home sales }\end{array}$ \\
\hline
\end{tabular}

* Self-employed. 
Among the males, 73 per cent. of those injured between I 5 and I9 years of age are quadriplegic, with 22 each from automobile and water accidents (including diving and surfing). Other causes, in order of frequency in this age and sex group, are motor-cycle accidents, sports (including four football injuries), falls, and gunshot wounds. Twelve of these males have married since injury, one subsequently having been divorced. Nineteen of these men are attending school; nine have full-time employment; six work part-time, some as self-employed persons. Thirty are not working. Living plans include 37 who live with their families; I I with wives; 9 with attendants; 7 in nursing homes; 5 alone and 2 by 'arrangements'.

Between the two extreme age-groups are the persons from age 20 to 40 at injury and accounting for 108 persons who were known to be living at follow-up. This was the age-group containing the most suicides, the highest incidence of unlawful behaviour prior to injury; the highest percentage living in nursing-homes. Although they demonstrated 3 per cent. higher employment rates than the younger subjects, the college enrolment rate was 20 per cent. lower than for the younger patients. This middle group reflects some habits of both extremes. Some are still being propelled forward by their individual life-styles; some seem to have had their early aspirations blunted by exposure to the world after leaving home and before they became fully established as independent adults. They, of the three groups, appear to be the most vulnerable to tragedy and the least predictable, and defied categorization in this study.

Several other areas of interest have been noted.

Types of Employment. Twenty-seven persons of the total 346 areemployed. These persons comprise a very disparate group in age, education, extent of disability and type of job (Table VI). Several other persons have been employed regularly in the past and for long periods of time. Pressure sores from long hours in wheelchairs have necessitated their return to hospitals, and in at least two cases (one a securities salesman, the other a hospital record technician) the persons are unemployed and on public assistance rolls.

Marital Status and Children. Marriage or the dissolution of marriage constitutes one of the most frequently discussed topics among staff members, families, patients' spouses and fiancées. Twenty males and four females in this series of cases have married since injury. Separation or divorce was reported by 27 persons. Equal numbers of paraplegic and quadriplegic persons married, but the divorce figure was higher among persons with cervical cord injuries. Determining the number of offspring among males in this series is a moot point and beyond the qualification of any but the most experienced medically trained paraplegists. Several females delivered infants normally and several families have adopted children.

\section{DISCUSSION}

The findings revealed by the age-group separations call attention to the fact that the older persons at injury seemed to be least effected by vocational and social rehabilitation efforts; that, although they learned some self-care, they needed help from family and attendants and demonstrated the least progress at follow-up. The 
youngest group seemed to be most melleable and responsive to all types of rehabilitation efforts and appeared to adapt to a complicated new way of life despite the particularly large number of cervical injuries among them.

Assistive Devices. The continuing use or disuse of special assistive devices by patients has been a subject of controversy among clinicians, orthotists and therapists in the Centre. Figures were not available accounting for the exact number of splints and braces initially prescribed and delivered to this series of patients. Following the recent interviews made as a part of this survey, the opinion was expressed that any assessment of this aspect of rehabilitation would necessitate a personal evaluation of the user and the device by a physician and/or a therapist and/or an orthotist.

Recommendations. A standard protocol for follow-up of spinal cord injured persons to be used by all centres interested in making comparative studies is recommended. Such a protocol should be the product of the thinking of members of the several disciplines constituting the centre rehabilitation team and completed with the co-operation of colleagues of other institutions.

Persons conducting follow-up should be fully oriented to the field of rehabilitation of spinal cord injured persons and the technics of interviewing and research methods.

Similar studies need to be made in other centres to establish progressively reliable data.

\section{REFERENCE}

Wilcox, N., Elane, Shannon Stauffer E., \& Nickel, Vernon L. (I970). A Statistical Analysis of 423 Consecutive Patients admitted to the Spinal Cord Injury Centre, Rancho Los Amigos Hospital, I January 1964 through 3 I December 1967. Paraplegia, 8, I, May 1970. 